\title{
I. Description of the island of Celebes or Macassar; with an account of its gold mines, and the manner of working them
}

\section{Mr. Von Wurmb}

To cite this article: Mr. Von Wurmb (1800) I. Description of the island of Celebes or Macassar; with an account of its gold mines, and the manner of working them, Philosophical Magazine Series 1, 6:24, 289-301, DOI: 10.1080/14786440008677227

To link to this article: http://dx.doi.org/10.1080/14786440008677227

曲 Published online: 25 Jan 2010.

Submit your article to this journal $\pi$

Џll Article views: 2

Q View related articles $\sqsubset$ 
THE

\section{PHILOSOPHICAL MAGAZINE.}

$M A Y 1800$.

1. Defcription of the Iland of Celebes or Macaffar; witb an Account of its Gold Mines, and the Manner of working them. By Mr. Von WurmB*.

\section{$\mathrm{T}$} importance to the Dutch $f$ for the fpice trade, on account of its fituation, as it has on the north the Philippines, on the weft the Sunda inles, on the eaft the Moluccas, and on the fouth Timor and Java. It extends from the third degree of north to the fifth of fouth latitude, and lies nearly under the 136th degree of longitude. It is about a hundred and twenty miles in length from north to fouth, and forty-five in breadth from eaft to weft. Raynal fays its diameter amounts to about a hundred and thirty miles, by which, in all probability, he underitood its length from north to fouth. Properly the eaftern fide of the inland is called Celebes, and the weftern Macaffar; but in general the former name is given to the whole ifland, particularly by the Dutch.

As this ifland lies under the line, the air is exceedingly hot; but the heat is moderated by frequent rains and cooling breezes, and in moft places the air is not prejudicial to the health of the inhabitants. It abounds with moun-

* From Merkwürdigkeiten aus Oflindien, publifhed by his brother.

+ This ifland, fince the author wrote, has fallen into the hands of the Englifh.

Vot, VI,

tains, 
tains, but the foil, taken in general, is fertile. Rice, coco. nut trees, mangoes, bananas, melons, and oranges, grow here exceedingly well, and are cultivated in abundance, together with the cotton thrub, $u b y$, and batta*. There are here alfo plenty of horfes, oxen, bulfaloes, deer, wild fwine, and birds of all kinds, and in particular a variety of beautiful parrots. Abundance of fifh are caught on the fea-coafts as well as in the rivers and lakes.

The Dutch carry hither opium, fpirits, lack, coarfe and fine cloths, \&c. and receive in exchange rice, wax, naves, and gold. Here, as well as in many parts on the coaft of Africa, the unfortunate beings doomed to navery are not prifoners taken in war, or criminals, but people in general who bave been kidnapped for the purpole of being fold ; and it often happens that relations do not hefitate, for the fake of gain, to deprive their fellow-creatures of liberty, the greateft bleffing which mankind enjoy in the prefent life. The ifland is well peopled: on the coaft of Celebes alone there are faid to be fifty-fix thoufand inhabitants, feventeen thoufand of whom are capable of bearing arms.

In this ifland there is a multitude of fmall kingdoms and ftates, the greater part of which, however, depend on the two great kingdoms of Macaflar and Bony. The king of Ternate, alfo, has extenfive poffeffions, which occupy almoft the whole of the northern and eaftern part of Celebes. The two moft powerful kings, whom the Dutch, by the preponderance of their arms, obtained as allies, are the kings of Macaffar and Bony. The kings of Tello and Sandrabony are in alliance with the king of Macaffar; and thofe of Soping, Luhu, and Tanette, with that of Bony. Some fmall ftates, fuch as Wadjo, Mandhaar, \&c. are independent. Though the kings of Macaffar and Bony are allies of the Dutch, they are always fworn enemies to each other; and this is not unfavourable to the policy of the Dutch, who in their Indian poffeffions ftill keep in view the maxim divide et impera, and

* Uyy is a root ufed as food, and batta is a kind of buck-wheat, which formerly was the chief food of the Javante before they were acquainted with the ufe of rice. 
who derive great advantage from the difcord of the eaftern princes.

The kingdom of Macaffar or Goach lies on the weftern fide of the ifland, of which it occupies the greater part. The king of Goach and that of Tello both bear the title of Macaffar, though each has a diftinet kingdom : they aflume the titles of Goach and Tello from their places of refidence. According to an ancient tradition, the Macaffars, like many other nations, deduce the origin of their princes immediately from the gods. Once, fay they, after the death of the firlt fovereign of the kingdom, a beautiful female defcended from heaven fufpended by a golden chain. This celeftial beauty, named Tumanurong-a, was immediately chofen by the $\mathrm{Ma}$ caffars to be their queen. She afterwards married a king of Bonthain, and, after being pregnant three years, brought forth a wonderful child, capable of fpeaking and walking as foon as it was born, but exceedingly ugly and deformed. This young prince was named Tuma-Salingabeerang. When he attained to manhood he broke the golden chain which his mother had brought with her from heaven, and the mother and her hufband inftantly difappeared, and left to their fon the kingdom, together with one half of the chain. This chain, which, it is afferted, was fometimes light and fometimes heavy, and fometimes appeared of a pale colour, was long preferved as a valuable part of the regalia of the crown, until it was lof, with various other rarities, during the warlike commotions which took place in this kingdom about the middle of the prefent century. This Tuma-Salingabeerang is confidered as the chief of the family of all the kings of Goach.

The Dutch were involved in violent difputes with thefe fovereigns before they were able to eftablifh themfelves in their kingdom. In the year 1778 Goach, the capital, was taken by ftorm and deftroyed; and in 1781 the prefent king Punduca Siri, fultan Abdal Hadja, was placed on the throne by the government of Batavia. The king of Goach does not enjoy unlimited power, but is fubject to certain laws, which he is obliged frictly to obferve. He can undertake no meafure of importance without the confent of his council, nor 
can he inflict arbitrary punithment on criminals, who muit be punifhed according to the laws. He has a privy council called Tonulalangs, and every village is under the direction of a particular governor diftinguifhed by the title of Galarang.

The Portuguefe vifited this ifland about the beginning of the fixteenth century, and obtained from the fovereign then on the throne permiffion to form an eftablifhment. The fucceffors of this prince introduced the weights and meafures now in ufe, fixed the prices of merchandife, manufactured gunpowder, and planted the firft cannon on the walls of Goach. He gave permiffion allo to the Malays not only to refide in his kingdom, but to erect a Mahometan temple. This religion made fuch progrefs here, that about the year I 588 deputies were fent to Mecca to bring from thence a hadja or prieft to inftuct the Macaffars in the doctrine of Mahometanifm, which in 1603 was eftablinhed throughout the whole kingdom under the fultan Allahudier.

The kingdom of Bony, which lies on the weftern fide of a bay, called on that account the Bay of Bony, is the fecond kingdom in point of importance in the ifland. It is in clofe alliance with the two fmall kingdoms of Soping and Luhu. The natives of Bony, that they may not appear inferior to the Macaffars, deduce their origin in the like manner from the gods. The firt king, they fay, defcended from heaven, and was known by the name of Matta-Solompo-e, that is, the all-feeing. This fovereign, after reigning forty years, refigned the kingdom to his fon, and with his wife afcended again to heaven: but, notwithftanding this common defcent of their rulers from the race of the gods, the Macaffars and people of Bony are fworn enemies, and their inceffant quarrels greatly contributed to enable the Dutch, who, according as their interen required, favoured fometimes the one party and fometimes the other, to make themfelves mafters of the inland. At prefent the Bouginefe, or people of Bony, are the molt powerful, as the Macaffars were about a century ago.

The Bouginefe are of a middle ftature, and have a brown complexion, but not dark. Among the female fex, in particular, fome are found almolt entirely fair. Their features in general are agreeable, only that the nofe is a little flatted. 
The Macaffars, on the other hand, are of large ftature, have a manly warlike appearance, are of a more open difpofition, and at the fame time deteft treachery; while their opponents, the Bouginefe, never attack openly, but endeavour to fall upon their enemies by furprife. Thofe even who never did them an injury are not fecure from being murdered by them when they can do it with privacy; and they often commit fuch actions for no other reafon, as they fay, than to try the goodnefs of their daggers. Many Macaffars, as well as Europeans, have fallen a facrifice to this thirft for blood. Their daggers and affagays are for the moft part poifoned, as well as their fmall darts, which they can thoot at their enemies to a confiderable diftance by blowing them through a tube.

Their clothing confilts of a piece of red or blue cotton cloth wrapped round the body, and drawn through between the legs. The upper part of the body is quite naked. On the head they wear a piece of cotton cloth in the form of a handkerchief, with which they cover their hair, which is as black as pitch, and exceedingly long. On the other parts of the body neither the men nor the women fuffer any hair to grow; they pull it out by the roots, in the fame manner as the Mahometans and Indians, as foon as it appears. They feed for the molt part on rice, filh, and pifangs; and their beverage is water, though they are not deftitute of fagueer, or palm wine. The Bonginefe women are in general much handfomer than thofe of the other Indian tribes: fome of them, had their complexion the fame mixture of red and white as our females, would be accounted beauties in Europe. They are naturally of an amorous difpofition, and are capable of undertaking any thing to gratify their inclinations.

The Mahometan religion, which has here become general, permits the Bouginefe to have four lawful wives, provided the hufband can maintain them. If the parties, however, are not fatisfied with each other, they may feparate with as little trouble as they were united. Their funerals are attended with very little ceremony. The body is wrapped up in a piece of white cotton cloth and depofited in the grave, over which fome fweet-fcented flowers are ftrewed, and two ftones are erected, one at the head and another at the feet. The 
Bouginefe have a fort of game at cards, which in all probability they learned from the Portuguefe. It has a great fimilarity to that called tarocco, though the twenty-two tarocs are not among their cards. The four colours are called fpada, datudyens cafo fokke, copas-coufel, and boelang-rofy.

As the Dutch readily faw the great importance of this ifland, particularly in regard to their fpice trade, they did every thing in their power to form a fettlement in it, and even at an annual expenfe, which confiderably exceeded the income arifing from their trade: the abbe Raynal makes it to be 165,000 livres. The caftle of Rotterdam, which is the principal refidence of their Eaft India company in the kingdom of Macaffar, lies in the latitude of $5^{\circ} 7^{\prime}$ fouth, and the longitude of $136^{\circ} 5^{\circ}$. It was conftructed by the Portuguefe with the affiftance of the Macafiars, and was afterwards beautified by the Dutch, who increafed its fortifications. Some years ago a neat church was erected here capable of containing two hundred perfons. The walls of the fortrefs, which are ftrong, and of confiderable height, are built entirely of ftone hewn from the rock. On coming out by the land-gate you arrive at a large plain, on the north fide of which lies the village of Blaardingen, where the principal part of the Europeans refide. The ftreets, which are broad, and ornamented with beautiful buildings, interfect each other at right angles in the direction of the four points of the compafs. At the end of one of them is a large edifice fet apart for an orphan-houfe. The Chinefe all live together in one ftreet, called for that reafon the Chinefe ftreet. Blaardingen is furrounded with palifacles, and is furnifhed with gates, which are fhut in the night-time. Without the palifades, towards the fouth, there is a row of buildings, one which is the habitation of the governor, and at a little diftance there are fome places called campongs inhabited by natives and Europears.

The road of Macaffar is one of the moft beautiful in India, and at the fame time fafe for thips at every feafon of the year. The diftrict around it is exceedingly pleafant. It confifts of a large plain feveral miles in extent, in which, as far as the eye can reach, nothing is to be feen but rice- 
fields and meadows watered by fmall ftreams. The picturefque appearance of this fcene is heightened by groves and fcattered clumps of thady trees loaded with fruit. Towards the eaft it is bounded by lofty mountains, called the mountains of Bonthain, which divide this part of Celebes towards the weft from Bony, and towards the fouth from the gulph of Tomini into two parts.

The feafons are here the fame as in Java. The fouth-eaft monfoon continues from May till November, and is called the favourable monfoon: the north-weft, ealled the bad monfoon, continues from November till May. During the former the $\mathrm{fky}$ is ferene and the weather dry; but continual winds and violent rain prevail during the latter. It is very fingular, that on the eaft fide of the before-mentioned mountains of Bonthain the contrary takes place: for, when fine weather in the fouth-eatt monfoon prevails on the weft fide of the mountains, there is nothing but hurricanes and rain on the eaft fide; fo that the boundaries of fummer and winter are only a few miles diftant from each other. The principal productions here are rice and cotton. The rice, however, is inferior in quality to that of Java, but the cotton is the beft in India.

The Dutch Eaft India company poffefs the caftle of Rotterdam, called in the language of the country Adjong Pandang, together with the furrounding diftrict, in confequence of a treaty which they entered into with the prince of Celebes. But as the boundaries of their poffeffions were perhaps not accurately defined, the company always endeavoured to enlarge, and the Macaffars on the other hand to confine them. The company poffefs alfo a peninfula extending from this place towards the north, and a large flat diftrict, which, on account of its fertility, is confidered as the granary of Celebes, together with feveral places lying between this plain and the mountains, and likewife a great many villages among the mountains. Thefe places border on each other, and are bounded on the weft by the fea, on the north by the kingdoms of Tanette and Maros, on the eaft by Tamari, and on the fouth by the kingdom of Macaffar. The inhabitants 
of them, after various revolts, were at laft reduced to complete obedience in $173^{8}$.

I thall omit faying any thing of the other fmall kingdoms in the ifland of Celebes, and proceed to a defcription of its gold mines, and the method in which the gold is collected. Mining and the art of metallurgy are conducted in a very carelefs manner in India ; which is owing partly to the ignorance of the natives, and partly to their indolence. In general it needs excite little furprife, that people who live in a mild climate, and who have few wants, thould be little inclined to penetrate into the bowels of the earth to procure metals, which are immediately extorted from them by the avaricious Europeans, or of which they are in a great meafure deprived by their own princes. If an Indian here and there be compelled by force or neceffity to dig for or collect gold, he never goes to work with fufficient intelligence and activity, but contents himfelf with what he can procure to fatisfy his wants in the eafieft and fpeedieft manner. This is exactly the cafe with the Indians who inhabit thofe parts of Celebes which produce gold.

They obtain that metal by collecting the fmall particles which have been carried down by the freams, or by wafhing the fand which they dig up, rather than by working the mines in a regular manner. The auriferous mines in the ifland of Celebes commence on the fouthern fide of Bulang and the northern fide of Kotta-Buna or Mogondo, and proceed thence to Dondo on the fouth-weft, and Tamperana on the north-weft fide, at the Bay of Tomini. Every where between thefe two diftrists gold is found in a greater or lefs quantity. Where the land of Celebes becomes fo narrow, and the mountains fo low, that a perfon can with eafe pafs from the one coaft to the other in a few hours, the auriferous mountains end; and on the whole coaft on the other fide, as far as Macaffar, a fingle gold mine is not to be found.

Befides the mines already difcovered, a great many others would no doubt be found, were there a fufficiency of labourers; for the villages in thefe auriferous mountains are exceedingly ill peopled. Another caufe of thefe treafures being 
fo much neglected is the ignorant fuperfition of the natives. They never will venture to dig in any place where they furpect great riches to be concealed until they have fent thither a diviner, as be is called, to find out whether their labours will be attended witli fuccefs. The whole art of thefe diviners, called in the languare of the country Talanga, confifts in their difcovering, as they pretend, by the voice of a certain bird, whether abundance of gold is to be found in a certain place; whether the labourers will be attacked by ficknefs; whether there are in it many fpirits to impede the labourers and conceal the gold from them, with other things of the like kind. If the bird gives a fayourable anfwer to all thefe queftions, the diviner muft endeavour to fecure the favour of the protecting fpirits of the place by offerings of various kinds; after which a few workmen may begin digging, and continue their labour as many days or months as the bird has prefcribed. If the bird, however, gives an unfavourable anfwer to only one queftion, no perfon will venture in fuch a place to dig a hole of only a few inches in depth. Many rich mines remain, therefore, mexplored, becaufe the prophetic bird, or the Talanga, are not in good humour.

When the workmen have arrived at the place where, according to the permition of the Talanga, they may dig up gold, they hold ferious counfel with the bird once more, and afk it in what particular fpot they muft begin. When this is done, they firft conduct water to the fpot; for without water they cannot proceed, as by its means they walh away the earth and clay from the pit, that the ftones and fine fand, among which the gold is contained, may remain pure. If the fituation of the ground will not admit of the water being conducted in furrows, they make a kind of gutters of hollow wakka trees, which they fupport with props. When they have brought the water to the place where the mine is to be worked, they make a pit of twenty, thirty, or forty feet in circumference, according to the number of workmen: fometimes there are eight, and fometimes ten or twelve. As long as the water has room to run off, they fuffer it to carry with it the earth, which they keep continually turning and firring in the pit; but when the pit becomes fo deep that there is VOL. VI.

Q q 
no paffage for the water, they muft bale it out till they arrive at the ftones. Thefe they wath clean, and build them up regularly around the fides of the pit, but without lime or mortar, to prevent the earth from falling in. When the pit is carried to a very great depth, they fecure thefe ftones by means of boards and beams of wood. Thefe poor miners find fometimes ftones of from three to four and five hundred weight, which they are obliged to raife and remove from the pit without any other machines than a common wooden lever.

When all the earth, clay, dirt, and ftones have been thrown from the pit, and a kind of black fand begins to appear, they are then fure that they thall find gold. This fand they take up in a kind of fmall hovels made for the purpofe; and, having placed themfelves in the water, they put one handful of the fand after another on fmall round wooden difhes named dulangs. Thefe dulangs are about eighteen inches in diameter and fomewhat hollow, and have a fmall cavity in the middle which can be clofed with a wooden cover. When all the fand has been wafhed from the dulang by being continually ftirred round with the hand, the gold, which is much heavier, remains in the abovementioned cavity. When it can receive no more, they take the gold which has been collected, and hold it over the fire in a coco-nut thell till it is dry; after which they blow away the remaining fand as well as they can, and preferve the pure gold.

When they dig a hill or mountain which is fituated clofe to a river, they employ another method to obtain the gold. In this cafe they make a pit at the edge of the river, conduct into it as much water as they have occafion for, throw into it the earth they have dug up, and wafh it till nothing remains but the black fand mixed with gold; after which they wath it in their dulangs, as already defcribed. This is the cafieft method of procuring gold, provided it can be employed. They have, however, a third method; but it can be ufed only in mines newly difcovered. They go into the river with a bafket on their back, and a piece of iron refembling a thick chifel, which has a wooden handle, and fearch the fiffures and crevices of the rocks, where they fometimes find lumps 
of gold equal in weight to two or three rials. In other refpects, the art of digging for gold is the fame in all the mines and among all the people on this coatt. The only difference is in regard to the depth of the pits. In many places it is fcarcely neceffary to go deeper than ten or twelve feet; but in others the pits muft be carried to the depth of feveral fathoms, and the fides muft be fupported by means of boards and beams. The inftruments ufed in thefe mines confift only of a piece of iron about a foot and a half long and two inches in thicknefs : it is pointed and harp at the one extremity, and at the other is furnilhed with a focket, into which is ftuck a wooden pole about fix feet in length. Thofe who are able to procure it have alfo an iron hook, with a fhort wooden handle, which they employ for loofening and turning up the earth around ftones. A mattock, with the abovementioned dulangs, which each miner makes for himfelf, and a pair of gold feales, form all the reft of their apparatus.

When a gold mine is difcovered, the workmen do not immediately begin to dig it, but firft fearch the neareft river, in which they turn up the ftones and drain off a part of the water. After they have turned up the fand to about the depth of a foot, they fometimes find large pieces of gold, which in all probability have been walhed down by the ftreams from the mountains. It has been remarked that the rocks on the borders of rivers, and even the greater part of the ftones which are taten up from pits where the ore is rich, have a blue, and fometimes yellow, colour, and are fo foft that they may be ufed as paint. Where the gold is lets rich, the ftones are gray or white, and either of a hard texture, or foft like limeftone. By thefe figns the produce in gold of any mine may be eafily afcertained.

In all the gold mines, but particularly thofe which lie at a diftance from the fhore, it is exceedingly cold before funrife and after fun-fet. On this account the poor miners fuffer a great deal. As they are obliged to fit in the water from morning till night, their bodies, when they ceafe from their labour, are almoft rendered quite white by the faltpetre. When the mines are worked, the water of the river near which they are fituated is muddy, and of a reddifh-yellow colov 
colour down to its mouth; and thofe who are fo imprudent as to drink of it are feized with a dangerous dyfentery.

The labour of the miners is not always attended with the fame fuccels; for it fometimes happens that they work a month and longer, during which they fpend feveral dollars, without finding gold of the value of one. In that cafe they are obliged to dig in fome other place, and to renew their labour. In newly difcovered mines they are for the moft part fuccefsful; but in mines that have been worked for fome time, they are often obliged to labour a whole month before they obtain any gold. The quantity and value of the gold which is found in any mine cannot be accurately afcertained. One workman, alfo, is often more fortunate than another. In newly difcovered mines there are labourers who fometimes, in the courie of fourteen days, find to the value of two hundred dollars; whereas in other places the value of twenty dollars is farcely found in the courfe of a year.

In the wide extended gold mines of the river Palella, which divides itfelf into feveral branches, there are places where gold is exceedingly abundant; but in fuch places it is of lefs value, being fcarcely cighteen carats fine. The bett gold comes from the mines of Popajatu, Molifipat, Ankahulu, Tolodinki, Lembuno, Somfro and Tamperana; alfo from the fouth and fouth-weft fide of Pogiama, Wongo, Tomollas Bevool, and Tontoly. The gold procured from all thefe mines is for the moft part above twenty carats fine. Frederick Dühr, a fervant of the Dutch Eaft India company, who vifited thefe mines a few years ago, is the only perfon who has given an authentic account of them. Thofe who travelled through thefe difricts before him, never faw the gold mines, but only vifited the habitations of the chief civil officers, which are at a confiderable diftance from the places where the gold is dug up; and the chief men among the natives are tno indolent to undertake journeys along thofe difficult and dangerous roads which conduct to the mines, and in which people are often in danger of breaking their necks.

Within the extent of the gold mines of Ankahulu there is a place called Longi, which produces a kind of gold that in finenefs 
finenefs exceeds even that of Popajatu and Ankahulu. This place, however, is little frequented, becaufe the fmall river near which it is fituated is not navigable, and the inhabitants are obliged to carry their provifions on their backs along a difficult and dangerous road. Befides, the miners often find in this place a great deal of copper, which, when they have no acid to put it to the teft, often deceives them, as they at firft take it to be gold. This is the only mine on the north or north-weft fide where copper is found. Near Bevool, on the fouth or fouth-weft fide, there is another where good copper is dug up in duft, which is as fine as the fineft goldduft. In the mines of Bombula, Batodulang, Ankahulu, and Palella, a great deal of rock-cryftal is found, and likewife a kind of iron ore.

In almoft all the mines which the before-mentioned $\mathbf{M r}$. Dühr vifited, he obferved, that the workmen, when they had dug to the depth of five, and in fome places of twelve feet, came to a horizontal ftratum of rock, which with their infruments they were not able to penetrate. They, however, frequently told him, that they firmly believed that they fhould find gold below thefe rocks, if they could break through them. He faw alfo at Ankahulu, where a ftratum of fuch rock is found, at the depth of from twelve to fifteen feet, that there were fiffures in it, two or three inches wide, which contained a blackifh fubftance almoft like ruft of iron, mixed with a great many pieces of gold, and which the workmen, after they wathed the rock perfectly clean, dug out to as great a. depth as they could with their tools. In all the mines of Celebes, the gold, when feparated from the fand, is of confiderable finenefs. At Pogiama and Palella alone gold ore is found here and there, mixed among other ftones; but it is not rich, and the gold muft be extracted by pounding the ftone, which is not very hard. 